Boletín de la Sociedad Geológica Mexicana

VOLUMEN 61, NÚM. 2, 2009, P. 199-202

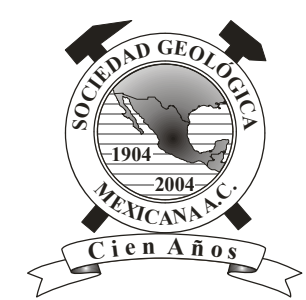

\title{
Ponotus shirahamensis, a new genus and species of raninid crab (Decapoda, Brachyura) from the Miocene Tanabe Group of Japan
}

\author{
Hiroaki Karasawa ${ }^{1, *}$, Masaaki Ohara ${ }^{2}$ \\ ${ }^{1}$ Mizunami Fossil Museum, Yamanouchi, Akeyo, Mizunami, Gifu 509-6132, Japan. \\ ${ }^{2}$ Wakayama Prefectural Museum of Natural History, Funao, Kainan, Wakayama 642-0001, Japan. \\ *GHA06103@nifty.com
}

\begin{abstract}
Ponotus shirahamensis, a new genus and species of the crab family Raninidae (Decapoda: Brachyura) is described from the lowermost middle Miocene Tanabe Group in Wakayama Prefecture of central Japan. Ponotus shirahamensis represents the second record for the family Raninidae from the Miocene deposits of Japan. Ponotus is most similar to Notopus, an extant monotypic genus of the Notopodinae, but is characterized by the absence of a spinose transverse ridge between the hepatic spines on the dorsal carapace.
\end{abstract}

Keywords: Crustacea, Decapoda, Japan, Miocene, Raninidae.

\section{Resumen}

Ponotus shirahamensis, un nuevo género y especie de la familia Raninidae de cangrejos (Decapoda: Brachyura) es descrita para el mioceno medio más inferior del Grupo Tanabe, en la Prefectura Wakayama de Japón central. Ponotus shirahamensis representa el segundo registro de la familia Raninidae en depósitos del Mioceno de Japón. Ponotus es muy similar a Notopus, un género monotípico existente de los Notopodinae, pero se diferencía por la ausencia de un pliegue transversal espinoso, entre las espinas hepáticas del caparazón dorsal.

Palabras clave: Crustacea, Decapoda, Japón, Mioceno, Raninidae. 


\section{Introduction}

The robust Miocene decapod crustacean fauna from Japan has been well documented (Karasawa, 1993, 1997, 1999; Kato, 1996). It consists of at least 113 species in 71 genera (Karasawa, unpublished data). Among these, the raninids are poorly known and only Macroacaena fudoujii (Karasawa, 2000) has been recorded from the early Miocene.

The purpose of this paper is to describe a new genus and species of raninid crab from the middle Miocene of Japan. The specimens were collected from fine-grained sandstone of the Shirahama Formation of the Tanabe Group exposed in beach of Migusazaki, Tsubaki, Shirahama-cho, Wakayama Prefecture (33 $37^{\prime} 7.2^{\prime \prime} \mathrm{N}$; $\left.135^{\circ} 23^{\prime} 22.1^{\prime \prime} \mathrm{E}\right)$. Macrofossils from the present locality are extremely rare and Ohara et al. (2001) only recorded pelecypods, Pholadomya turunagai Tan and Atrina sp. The ichnofossil Thalassinoides sp. is most common in the sediments (Ohara et al., 2001). Tanabe Research Group (1984) assigned the Tanabe Group to Zone N8b (earliest middle Miocene) of Blow's scale of planktonic foraminifera. Ohara et al. (2001) suggested that the sedimentary environments in which the rocks were deposited were the upper shoreface to inner shelf based upon lithological analysis.

The described specimens are deposited in the Wakayama Prefectural Museum of Natural History (WMNH-Ge) and the Mizunami Fossil Museum (MFM).

\section{Systematics}

Superfamily Raninoidea de Haan, 1839

Family Raninidae de Haan, 1839

Subfamily Notopodinae Serène and Umali, 1972

\section{Genus Ponotus new genus}

Type species. Ponotus shirahamensis new species, by monotypy.

Diagnosis. As for species.

Etymology. Ponotus is an anagram of Notopus de Haan, 1841; masculine gender.

Geologic range. Early Middle Miocene.

Discussion. See species discussion.

\section{Ponotus shirahamensis new species} Figure 1

Diagnosis. Carapace moderate-sized for Notopodinae, ovoid, much longer than wide. Fronto-orbital margin wide, about $75 \%$ maximum width; rostrum simple, short, broadly triangular, with median dorsal carina; orbital margin with shallow orbital fissure outside intra-orbital spine and 2 orbital spines; intra-orbital spine slightly directed anterolaterally; outer-orbital spine directed anteriorly.
Anterolateral margin slightly sinuous with short hepatic spine. Posterolateral margin gently convex, weakly rimmed. Posterior margin slightly convex, weakly rimmed. Dorsal surface strongly convex transversely, gently convex longitudinally; regions not defined; anterior surface with coarse granules, anterolateral portion rugose, and other surfaces punctate; transverse ridge between hepatic spines absent; weak median longitudinal carina present. Chelipeds similar in size and shape; lateral surfaces of merus, carpus, and propodus terraced ridges; propodus subtriangular, compressed laterally, about as long as high; fixed finger short; dactylus narrow, long, strongly curved ventrally, without teeth or spines on dorsal and occlusal margins.

Etymology. The trivial name notes the occurrence of the specimens in Shirahama-cho.

Description. Moderate-sized notopodine. Carapace ovoid, much longer than wide, maximum width about $67 \%$ maximum length, maximum width as measured between anterolateral spines. Fronto-orbital margin wide, about $75 \%$ carapace width. Rostrum short, simple, triangular, slightly downturned, with dorsal carina marked by lateral grooves. Orbital margin concave, smooth, bearing shallow fissure outside intra-orbital spine. Intraorbital spine triangular, directed slightly anterolaterally. Outer-orbital spine directed anteriorly, slightly longer than intra-orbital spine. Anterolateral margins short, slightly sinuous, subparallel, with short, anterolaterally directed hepatic spine. Posterolateral margins much longer than anterolateral margins, gently convex, weakly rimmed, divergent posteriorly. Posterior margin slightly convex, weakly rimmed, about $47 \%$ carapace width.

Dorsal surface strongly convex transversely, gently convex longitudinally. Dorsal regions not defined. Anterior surface with coarse granules, anterolateral portion rugose, and other surfaces punctate. Median longitudinal carina present, weak, extending from rostral carina to cardiac region.

Anterior thoracic sternites preserved, nearly flattened ventrally. Sternites 1-3 fused, small, with strongly convex lateral margins. Sternal sutures $3 / 4$ and $4 / 5$ absent. Sternite 4 broad; anterior margin nearly straight; lateral margin concave. Sternite 5 poorly known with shallow median sulcus.

Chelipeds similar in size and shape. Merus much longer than high; dorsal and lateral surfaces with terraced ridges. Carpus slightly shorter than merus; lateral surface with terraced ridges. Propodus subtriangular, compressed laterally, about as long as high, about as long as carpus; lateral surface with terraced ridges; dorsal margin short, convex, smooth; ventral margin sinuous, smooth; proximal margin deeply concave; distal margin sharp with irregular, broad teeth. Fixed finger short, poorly preserved. Dactylus narrow, long, strongly curved downward, without teeth or spines on dorsal and occlusal margins.

Some pereiopods known, but poorly preserved. 


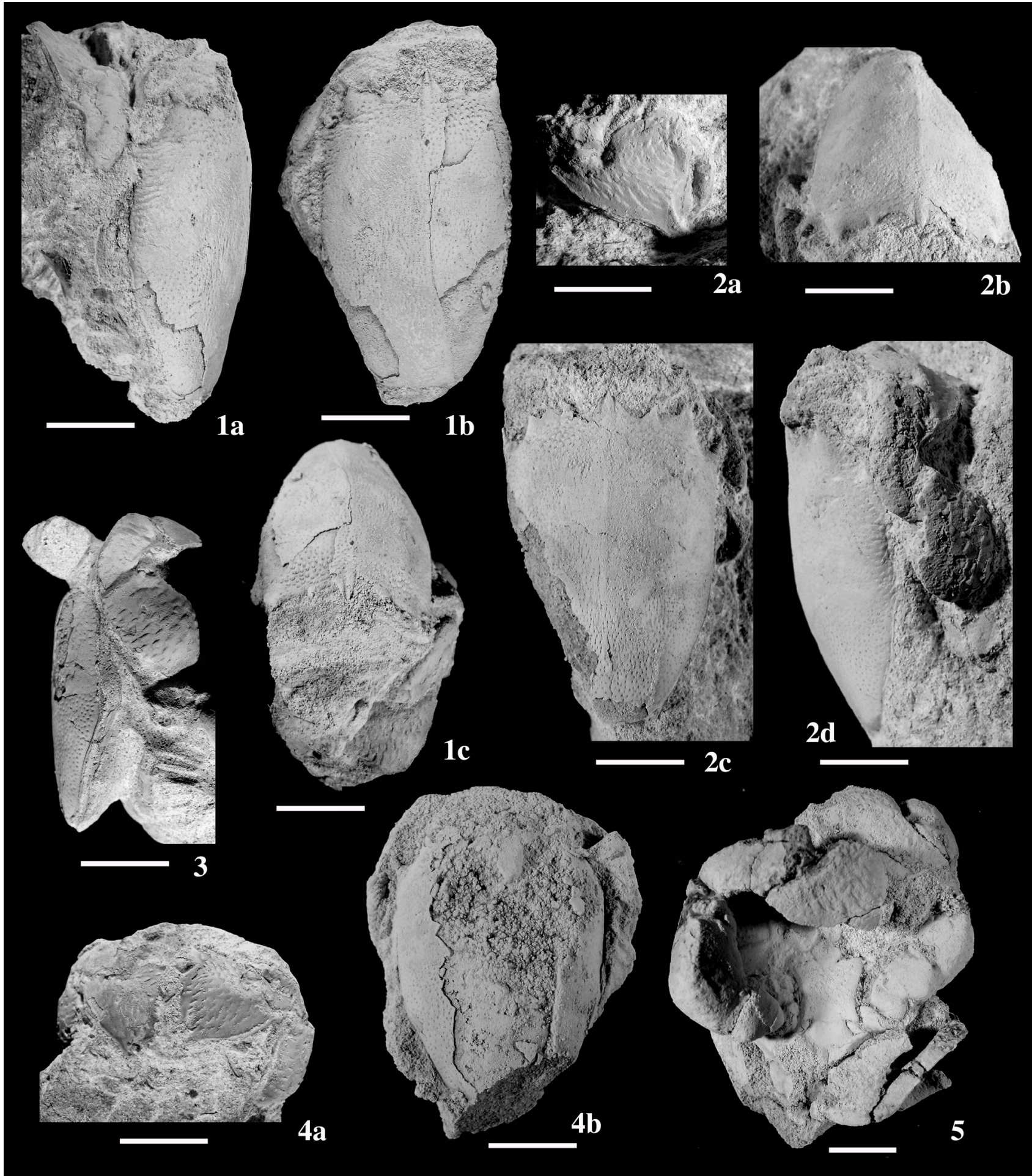

Figure 1. Ponotus shirahamensis new genus and species. 1a-c, MFM83067 (paratype), carapace and chelipeds, 1a, lateral; 1b, dorsal; 1c, frontal view. 2a-d, WMNH-Ge-112012007 (holotype), 2a, right chelipeds, lateral view; 2b, carapace, frontal view; 2c, carapace, dorsal view; 2d, carapace and right cheliped, lateral view. 3, WMNH-Ge-112012024 (paratype), carapace and right cheliped, lateral view. 4a, b, MFM83068 (paratype), 4a, chelipeds, lateral view; 4b, carapace and chelipeds, dorsal view. 5, WMNH-Ge-112012006 (paratype), thoracic sternum, chelipeds, and pereiopods, ventral view. Bar equal to $10 \mathrm{~mm}$. 


\section{Discussion}

There is, in the general outline of the carapace, similarity between the present new genus and Notopus de Haan, 1841, an extant monotypic genus of the Notopodinae. However, the new genus lacks a spinose, transverse ridge between hepatic spines on the dorsal carapace, which is a diagnostic character of Notopus. Additionally, in the new genus the upper orbital margin is smooth and an anterior region of the dorsal carapace is covered with coarse granules, while Notopus has a spinose upper orbital margin and spinose anterior dorsal carapace regions. The new genus also resembles the other notopodine genus Ranilia Milne Edwards, 1837, but differs in the presence of two pairs of orbital spines, a short, broad rostrum, and a median dorsal carina of the carapace. Ranilia possesses three pairs of orbital spines, a long, narrow rostrum, and lacks a median dorsal carina of the carapace.

\section{Material examined}

Holotype, WMNH-Ge-112012007; paratypes, WMNHGe-112012006, WMNH-Ge-112012024, MFM83067, MFM83068.

\section{Acknowledgments}

We thank Y. Okumura (MFM) and Y. Sako (Kushimoto, Wakayama) for supporting our field work and F. J. Vega (Universidad Nacional Autónoma de México) for assisting in our manuscript. We are grateful for the reviews by R. M. Feldmann (Kent State University), R. W. Portell (Florida Museum of Natural History) and F. J. Vega.

\section{References}

de Haan, W., 1833-1850, Crustacea, in Siebold, P. F. von (ed.), Fauna Japonica sive descriptio animalium, quae in Itinere per Japoniam, Jussu et auspiciis superiorum, qui Summun in India Batava Imperium tenent, suscepto, annis 1823-1830 collegit, notis, observationibus et adumbrationibus illustravit; Ludguni-Batavorum, i-xvii $+\mathrm{i}$-xxxi + ix-Xvi + 1-243, pls. A-J + L-Q + 1-55.

Karasawa, H., 1993, Cenozoic decapod Crustacea from southwest Japan: Bulletin of the Mizunami Fossil Museum, 20, 1-92, 24 pls.

Karasawa, H., 1997, A monograph of Cenozoic stomatopod, decapod, isopod and amphipod Crustacea from west Japan: Monograph of the Mizunami Fossil Museum, 8, 1-81, 30 pls.

Karasawa, H., 1999, The Cenozoic decapod crustacean fauna of southwest Japan, in Schram F.R., von Vaupel Klein J.C. (eds.), Crustaceans and the Biodiversity Crisis: Proceedings of the Fourth International Crustacean Congress, Amsterdam, The Netherlands, July 20-24, 1998, vol. I. Brill, Leiden, 29-44.

Karasawa, H., 2000, A new raninid crab (Crustacea: Decapoda: Brachyura) from the Kase Formation (lower Miocene) of Kyushu, Japan: Proceedings of the Biological Society of Washington, 113, 806-809.

Kato, H., 1996, Miocene decapod Crustacea from the Chichibu Basin, central Japan: Transactions and Proceedings of the Palaeontological Society of Japan, new series, 183, 500-521.

Milne Edwards, H., 1837, Histoire naturelle des Crustacés, comprenant l'anatomie, la physiologie, et la classification de ces animaux, Paris, 2, $532 \mathrm{p}$.

Ohara, M., Hisatomi, K., Sako, Y., 2001, Pholadomya from the Miocene Tanabe Group of Shirahama-cho, Wakayama Prefecture: Annual Report of the Wakayama Prefectural Museum of Natural History, 19, 41-50.

Serène, R., Umali, A.F., 1972, The family Raninidae and other new and rare species of brachyuran decapods from the Philippines and adjacent regions: The Philippine Journal of Science, 99, 21-105, pls. 1-9.

Tanabe Research Group, 1984, Stratigraphy and geological structure of the Tanabe Group in the Kii Peninsula, southwest Japan: Earth Sciences, 38, 249-263.

Manuscript received: February 27, 2009

Corrected manuscript received: June 10, 2009.

Manuscript accepted: June 15, 2009. 